\title{
Közelítések egy integrációs látleletről
}

\author{
Két könyv, egyazon fázis, harmadik olvasat
}

Kovách Imre (szerk.) (2020): Integrációs mechanizmusok a magyar társadalomban MTA Társadalomtudományi Kutatóközpont - Argumentum, Budapest, 377 oldal Kovách Imre (szerk.) (2020): Mobilitás és integráció a magyar társadalomban MTA Társadalomtudományi Kutatóközpont - Argumentum, Budapest, 432 oldal

\section{A. GERGELY ANDRÁS ${ }^{1}$}
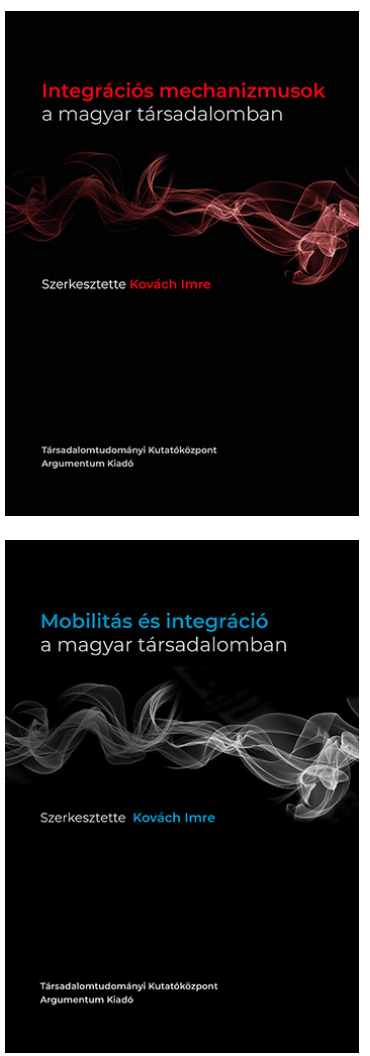

Ahogy a kutatót a fölhalmozódó forrásanyag, oszlopokba rendeződő adattömeg, feltárt új ismeret serkenti egységbe foglalni a tudástapasztalatot, úgy kellene talán összegzésre bírja a megjelenített anyag a recenzenst is. A prezentáció felelőssége, a közlés relevanciája így ugyan messze nem összevethető, ám a nyilvánosság kockázata talán közös annyiban, vagy legalábbis megosztható, ha a reflexió méltóképpen föl képes emelkedni a kutató(k) közlő szándékához. Két ekkora, s ily módon árnyalt tanulmánykötet esetében ez nem is kevés rizikóval kecsegtet, de mert a próbatétel nélkül kevesebbet is ér, inkább csak „megszolgálni” próbálhatom a bizalmat, mely reflexióra bírt e téren.

A kézbe kapott kötetek (mert mindjárt párban kiadott művekről esik majd szó) első tekintetre is impozáns, már a küllemre is speciális gondot fordító munkák. Élmény kézbe venni az elegánsan öltöztetett műveket, melyeket ízléses, rangképes, megfontolt komolyság tömör pompája jellemez - kissé talányosra formálva is a fedőlapra illesztett illanékonyság hangulatával (Kovács Mariann választékos munkájaként). Ez fontos. Érdektelen küllemű kötetnél még belelapozni is próbatétel - ezek viszont csábítják a kezet a megértés felé közelíteni. Ráadásképpen mintegy szerencsésen fedik, leplezik is a szándékot, mely „címkézett olvasótáborként" azonnal kiválasztja azt a három tucat értelmiségit, akit efféle kérdések még érdekelnek, s

${ }^{1}$ ELTE TáTk Kulturális Antropológia Tanszék, email: andrasgergelya@gmail.com 


\section{RECENZIÓ}

ezektől is elmarad valahol a közérdeklődés vagy a szakmai kíváncsiság, mely a társadalmi tudás, politikai vagy gazdasági rálátás köztes szférájába emelhetné az érintett tömegek számára is relevánsnak minősülő elemzések egész tudástárát.

Nem könnyen engedődik meg olyasféle észrevétel, mely abból indul ki, hogy a társadalmi struktúra kutatásában (legalább) a nyolcvanas évek óta életvitelszerűen jelenlévő Kovách Imre és kutatói köre más érdekeltségi és értelmezési igényt formál efféle tartalmak publikálására, mint a politikai vagy akár a közgondolkodási többség, vagy éppen e recenzió készítője. Nem vagyok eléggé „empirikus társadalomkutató” ahhoz, hogy módom volna megfaggatni - nem a legszélesebb társadalmi érintettségi kört, de legalább - az elvben érdekelt szociológusokat arról, miképpen vélekednek a társadalmi struktúra jelenéről és az ebbe integráló hatások köréről. De félem a várható válaszok jellemző többségét, hogy ugyanis még vélekedni is vétek ilyesmiről olyankor, midőn maga a struktúra, s mögötte még inkább maguk az érintettek társadalmi körei a totális, kezelhetetlen, átláthatatlan átmenet fázisában érezhetik magukat, s róluk „érvényeset” vélekedni is merénylet vagy erős kockázat lehet. Ekképpen a két kötet szinte flegma távolságtartásra késztet, ha a magam struktúra-elméleti igényére és a lehetséges válaszkísérletekre gondolok, s azt is belátom, ha csak engem késztet kételyekre - de félem, a lehetségesen érdekelt többséget is ugyanígy.

Innen jó veszteni! Sőt, mert már a nyolcvanas évek társadalomtudományi szakmai vitáit (a rétegződés - modell - vizsgálat kulcskérdéseire hangolt sok kötetben) is felhangolta az alapvető problematika, mely a struktúra- vagy kultúraorientált felfogásmódok lehetségességével számolt, ezt a tetten érhető két dimenziót pedig az alábbiakban is a két testvérkötet látszólagos elkülönítésével tagolom - jóllehet, ez a belátó rálátás már önmagában is adná egy harmadik olvasat lehetőségét.

\section{Az alapstruktúrá(k)ról}

Már az Integrációs mechanizmusok a magyar társadalomban címú kötet ${ }^{2}$ szerkesztői előszava is jelzi, mennyiben mondható egységesnek a szerzői tanulmányok szerves illeszkedése a kutatási projektben megnevezett témakörben, de egyúttal meg is állapítja: „A tanulmányok a rendszerintegráció, társadalmi integráció és személyközi integráció szintjein elemzik az integrációs mechanizmusok működését és annak hatásait. Integrációs mechanizmusoknak tekintik azokat az intézményi, csoportos esetleg egyéni cselekvéseket, beállítódásokat, képzeteket, értékeket és normákat, amelyek létrehozzák, javítják, lehetővé teszik az integráció szereplőinek együttműködését, növelik az összetartozás érzetét, csökkentik vagy megelőzik az integrációval kapcsolatos kommunikáció zavarainak és a konfliktusok kialakulásának lehető-

${ }^{2}$ Kovách Imre (szerk.) (2020): Mobilitás és integráció a magyar társadalomban. MTA Társadalomtudományi Kutatóközpont - Argumentum Kiadó, Budapest, 432 oldal 


\section{RECENZIÓ}

ségét vagy elmélyülését." (7. old.) Így hát (legalább) három integrációs szint, három kiterjedés és ötféle főbb dimenzió mentén keletkezett elemzésekről van szó. Ezek mindegyike mint tudományos igényű tanulmány is, további ágak és bogak, szempontok és nézőpontok, perspektívák és kölcsönhatások, technikák és kihívások, helyzetek és válaszok sokasága felé vezeti tovább az érdeklődő tekintetét. $S$ ha a legfelszínesebben is komolyan vesszük, hogy egy műhelymunka egyetlen tanulmánya körül egy alkalmi vitában még hány további szempont, hiányérzet, belátási igény, magyarázat, értelmezési horizont vagy szűkítési-lokalizálási igény jelenik meg, akkor talán átlátható a recenzens dilemmája, miként is lehetne négy fejezetbe tagolt tíz szakmai tanulmányt egyetlen olvasati perspektívából fölbecsülni. E sejtelmes képtelenség vállalását szívesen bízom másokra, magam itt egy „kívülnézeti” optikával tekintek most a dolgozatok összességére, s biztos lehetek abban, hogy temérdek szükséges méltánylási szempontot figyelmen kívül fogok hagyni. Ezt azonban nem bánom, szinte bárki más olvasóval is meg fog esni hasonló. De mert tanulmánykötet, melynek polcunkon a helye, még semmi sem ment veszendőbe, idővel újra elővehető, forgatható, összehasonlítható, mérlegelhető marad további rákérdezések alkalmával is. Együttesen is, esettanulmányi értékeik kiemelésével is.

Lehet, talán leginkább akkor járok el korrektül, ha a lehetséges olvasót rögtön az ismerkedés fázisába is beavatom. Példaképpen: megpróbáltam rákeresni a négyszáz oldalnyi szövegben, hova, avagy mibe is integrál mindaz, ami mechanizmusként ezt segítené vagy épp gátolná. Mert hát valahol és valahogyan kellene lennie valaminő integrációs, beilleszkedési, bentmaradási, valahová-tartozási eredendő célnak, társadalmi késztetésnek is... A keresés eredménytelen maradt, mintegy evidenciaként tételeződik, hogy van „A” társadalom, van egyéni és csoportos és rétegződési és részesedési integrációs szint, s vannak egyenlőtlenségek a társas együttlét strukturális eredőit, hatásait tekintve. Tehát alapszinten egy konszenzusból indulunk: van társadalomképünk, van olyasmi, amit szinte közös nevezővel, egyetértéssel társadalomnak tekintünk, s amihez minden egyénnek vagy közösségnek kell lennie valamely kapcsolódási pontjainak, szintjeinek, kötődéseinek, akaródzásainak. Ezzel máris alapgondom van, s a tanulmányok ebben nem megcáfolnak, hanem eligazító módon meg is erősítenek. Ez leginkább az a „távolságtartó”, indifferens (hogy ne mondjunk „objektívat” véletlenül sem) rálátás, mely nem belül-, hanem kívülálló, vagyis feltételezi, hogy mintegy konszenzussal beszélhetünk egyfajta elvont társadalmi valóságról vagy valóságképről, melyben viszonylag könnyeden egyetérthetünk, ami ezúttal a valamibe-beilleszkedés késztetése. S persze, nem tudományos konszenzus kérdése, avagy még kevésbé megegyezéses feltétel, hogy tételezünk egy nagy egészet, melynek részeiként és rétegeiként további elemek megnevezhetőségét posztuláljuk. Annyi viszont a kiindulás alapjaihoz tartozik akkor, hogy mintha egységes képünk lenne arról, mit nevezünk társadalmiságnak, egyének helyzetének, pozícióknak, státuszoknak, javakhoz jutásnak és elosztásnak, részesültségnek vagy dezintegráltságnak akár. Nem „leckekönyvi” tézisre vágyom, de arra igen, kerülhes- 


\section{RECENZIÓ}

sen valahol elő egy képzet úgy, hogy annak paraméterei világossá tettek számomra is. A „rákeresés” gesztusa innen indult: amennyiben a társadalom mint létező föltétlenül egy képzetes nagy egész, amibe integrálódik az alárendelt népesség, akkor már sokkalta inkább nemzeti, állami, politikai, képzetes univerzumról van szó, vagy éppen lakóhelyi, származási közösségről, mint akár az egyes tematikus tanulmányok körében bármelyik írásban. Ez mint dilemma bizonnyal „iskolás kérdés”, avagy alapismeret a struktúrakutatóknak, de nem az magának az Ismeretlen Olvasónak. Már az első, mintegy keretet is adó tanulmány Társadalmi integráció és társadalmi rétegződés címen (Huszár Ákos, Kovách Imre, Kristóf Luca és Szabó Andrea írása, 11-43. old.) igyekszik eligazítani abban a gondolatkörben, ahogyan a társadalmak kutatásának tudománytörténetében az új- és legújabb kori tárgyalásmódok kezelték ezt a válaszlehetőséget (Marx, Weber, s fóképpen Merton alapján), amihez nemcsak szaktárgyi olvasottság kell, de mérlegelési aspektus is. A szerzők ennek nyilván birtokában vannak, de úgy vélem, messze nemcsak a szaktudományi optika kell itt érvényesüljön, legalább ennyire szükség volna a „legáltalánosabbnak” mondható vagy legszélesebb értelmű társadalmiság értelmezési hálójának elmélettörténeti körvonalaira is. A szerzők viszont erre kifejezetten nem vállalkoznak, eleve szúkítenek és pontosítanak társadalmi integráció, a kapcsolatok, az egyenlőtlenségek, a normák, a részvétel módjai és specifikusan a szubjektív kirekesztődés területére. „A tanulmány témája a társadalmi rétegződés és integráció összefüggése, amelyet 2015-ben és 2018-ban felvett kvantitatív adatokon elemeztünk. Bemutatjuk az integrációs modell létrehozásának részleteit, a felhasznált dimenziók konstruálását és változásait a két felvételi időpont között. Választ kerestünk arra, hogy a normatív funkcionalista rétegződésmodell elemzésbe vonásával hogyan lehet jobban megérteni a társadalmi pozíció és az integráltság egymásra hatását és az ezt elősegítő, kikényszerítő integrációs mechanizmusok múködését. Eredményeink szerint a foglalkozási csoportok és a vizsgált integrációs mechanizmusok között értelmezhető összefüggés mutatható ki. Az osztálymodell felső rétegei (leginkább a vállalkozók, a vezetők és értelmiségiek, az egyéb szellemiek) következetesen magasabb gyenge kötésszámról, alacsonyabb kirekesztettségérzetről és magasabb politikai részvételről számoltak be. Szintén nagyon hasonló, csak éppen pont fordított előjelű eredményeket tapasztaltunk a foglalkozáson alapuló modell alsó rétegeinél, leginkább a munkanélkülieknél és az alacsonyabb képzettséghez kötött segéd- és betanított munkát végzőknél. Ami talán a legérdekesebb fejlemény, hogy a munkaerőpiacról való kilépés, egész pontosan a nyugdíjas korba való belépés és a jelenlegi nyugdíjas státus nem változtatta meg lényegesen a gazdaságilag aktív időszakból eredő társadalmi előnyöket és hátrányokat." (411. old.)

Röviden: ha itt a történeti, tudományelméleti, metodikai vagy struktúra-leképezési látószög kellően körvonalazatlan marad, miként lesz hitelessé az utána következő további tanulmányok sora? Hogy kérdésem (a „mibe” és „hova”) az integráltság, a személyi/perszonális integritást beleértő, vagy azt feltételül kezelő szemlélődés 


\section{RECENZIÓ}

része-e, kissé indokolnom kell. A nemcsak szigorúan „szótári” értelemben vett integráció a teljes egészhez való viszonyt jelzi vagy utalja, ez valószerű. Ugyanakkor - s ez az, amit a beilleszkedési mechanizmusok kötet az elvontság szintjén látszik kezelni, s a másik, a térbeli, csoportbeli, identitási és mobilitási kérdéseket taglaló kötet már emberközelibb valóságában tételez - a társadalom egésze mint integrált egység okkal teszi feltételezhetővé, hogy nem egységességről és egyenlőségről van szó, hanem a beilleszkedés tudatos, megfogalmazott, vállalt, stratégiává vagy cselekvési normává tett szándékról, társas létformák és közösségek saját struktúráját kiadó számosságról, felépítményről, formaegészről. De hogyan is lehet azt az „optikailag” egységnek tetsző univerzumot valóban élő közösségek összefüggésrendszerévé téve rákérdezni az egyes rész-egészek viszonyára és kapcsolatrendjére? Együgyübben fogalmazva: ha én kérdezett vagyok, és integráltságom a kérdés, alapszinten viszszakérdezek: miért, én így magamban és megannyi egyesítő, elkülönítő, hasonlóvá tevő vagy megkülönböztető jegyemmel együtt nem vagyok egy integráció része? Nem vagyok beilleszkedett, csak akkor, ha neve van az illeszkedésnek, ha kódja van a hovatartozásnak, ha iránya van a törekvésnek, ha célja és normája a sikerének? (Emlékezetes még az egykori struktúravizsgálatok ellenpontján a Somlai Péter által fölvett szempontegyüttes, melynek módszertana és a társadalmi betagolódásra építő kérdéskörei a szocializáció jóval intimebb oldaláról közelítettek mindehhez „Kiilleszkedési zavarok" címen, 1989-ben.) Nos ez az, amit a kötet (s részint a másik is) oly módon vesz evidenciának, hogy föl sem merül az integráció mint cél, az integráltság mint rang, a beilleszkedési és hovátartozási állapot mint készség vagy szándék függvénye, magyarán a vállaltan-tudatosan-célzatosan elért strukturális pozíció és az elszenvedett, szubjektív életvilágok kölcsönhatásaként létrejött entitások különbségeinek szükséges részletrajza. Ezzel, úgy vélem, és egynémely szakirodalmi bóklászás meg is erősít ebben: a mai integrációs vizsgálódások köre azt teszi kétségessé, hogy akinek nincsen deklarált/deklarálható egységesülési törekvése, beilleszkedési célja, alkalmazkodási modellje, csatlakozási aspirációja vagy beolvadási programja, az nem is része a nagybetús társadalomnak, így nem lehet alanya az összehangolódás és hovátartozás teljességének - ami pedig amúgy is meghatározhatatlan -, egyben tehát magának a kutatásnak is csupán esetlegesen válhat részévé. Hol van tehát a „nem-integrált” egyed ebben a folyamatban, akinek alkalmazkodási, betagolódási, hozzárendelődési, egybemosódási célja nincs vagy nem kifejezhető, de mégis része az egésznek, ha akarja, ha nem?

A részválasz, de könnyedén elfogadható replika azonban - a különösebben mély személyiségfejlődési vagy szociálintegratív adottságokkal részletesen számolni képes feltételrendszer nélkül is - az, amit a bevezető fejezet rögtön részkérdésekre, integrációs szintek sorára bont. „A rendszerintegráció szintjét a politikai alrendszerrel összefüggő mechanizmusok és tudások, az intézmények, valamint legalább részben a normák és értékek fedik le. A politikai értékek és annak differenciálódása, az értékvilág ugyanis tárgya a politikai kultúrának és a politikai szocializációs szakiroda- 


\section{RECENZIÓ}

lomnak egyaránt. A társadalmi integrációhoz tartoznak a redisztribúciós mechanizmusok, amelyek a társadalom különböző rétegei között újraosztják a rendelkezésre álló forrásokat (Czibere et al. 2017, Csanádi 2020). Nyilvánvaló a térbeliségnek, a lokalitásnak, másként a területi integrációnak a társadalmi integrációhoz tartozása is (Csurgó et al. 2017), amelynek a Kovách-féle értelmezés alapján a hagyományos foglalkozási alapú rétegződés problematikája is a része. Az integrációs modell és a korábban használt, elsősorban foglalkozásalapú modellek összehasonlításának egyik eredménye az volt, hogy az integrációs modell használata jelentős módon bővíti a magyar társadalom valós tagozódásával kapcsolatos ismereteket, azokat új szempontokkal egészíti ki (Kovách et al. 2016)." (14. old.) A kutatások egésze (tételezve, hogy az összesség elvben az egész is) tehát itt eleve az integráció típusait, modelljeit tekinti az integráltság teljességének, s ennyiben alapszintű részválaszt is ad alapkérdésemre: ha így elemezzük, így vesszük, akkor ez az integráció-fogalom és az a társadalmi összkép mint együttes aspektus ebben a modellben és a maga módján harmóniában is van. Ebből fakadóan mintegy a modell részeként kezelt személyközi integrációhoz tartozó értékek pedig a három komponensű rétegződési modellnek úgy részei, hogy a hagyományos rétegződésmodellek és -sémák mellett olyan viszonyrendszert formálnak képletté, melyben „a társadalom felső és alsó csoportjainak jellemzőit” megjelenítő leírás „minden más modellnél érthetőbbé teszi a középrétegek differenciálódását előidéző folyamatokat és társadalmi mechanizmusokat" mutató keretrendszert, hogy ezekkel az új kutatások új aspektusaival új „empirikusan megragadó dimenziókat” sikerüljön létrehozni (15. old.). A társadalmi integráció különböző dimenziót az integrációhoz és a dezintegrációhoz kapcsolódó problémákkal együttesen mérlegelő társadalomszerkezeti modell pedig (a hagyományos foglalkozásalapú modell mellett) a foglalkozásra építő csoportosítások, rétegsémák és látens osztálymodell-leírás mellett a társadalmitőke-változók (így a kapcsolatok, a bizalom és a részvétel) bevonását is alkalmasnak látták az elemzésre, a hagyományos modellekkel leírt rétegződési és strukturális egyenlőtlenségek megjelenítésére, s ezekhez képest a társadalmi integráltság egyéb indikátorai (szubjektív társadalmi kirekesztettség, szubjektív társadalmi fontosság, normakövetés, munkaintenzitás) bevonására is kísérleti bizonyítást tettek, a korábbi modellek és foglalkozásalapú rétegződéssémák magyarázó erejét kiegészítve az integráltság magasabb szintű társadalmi tőkével együtt járó változóival. (14. old.) „Ennek a tanulmánynak az elsődleges kérdése az, hogy a társadalom különböző csoportjai miként és minek a következtében integrálódnak a magyar társadalomba és milyen integrációs mechanizmusok segítik elő vagy éppen gátolják a különböző társadalmi helyzetűek integrációját. A kulturális célok eléréséhez rendelt intézményes eszközök a társadalmi integráció több egymástól eltérő dimenzióján keresztül megjelennek (vö. Dupcsik - Szabari 2015, Kovách et al. 2017), amelyek a dezintegráció különböző fajtáiról tájékoztatnak. A lehetséges dimenziók közül négyet vizsgálunk: a politikai 


\section{RECENZIÓ}

részvételt, valamint a gyenge kötések számát, azaz a nexusdiverzitást, a társadalmi kirekesztődés érzékelését és a normakövetést." (12. old.)

A kicsit szándékoltan is „tudálékoskodó” kérdésemre kapott hamari válasz („a sokféléből most négyet vizsgálunk”) tehát már az első tanulmányból leágaztatható, ehhez pedig a szerkesztő, Kovách Imre, a kötet szerkezetének pontosító keresztmetszetét is adja bevezetőjében: „A társadalmi egyenlőtlenségekkel foglalkozó blokk első két tanulmánya amellett, hogy megkerülhetetlen jelentőségű kutatási eredményeket ad közre a rétegződés és integráció kapcsolatáról és a politikai integrációról, az integrációs mechanizmusok fogalmának az értelmezéséhez történő elméleti igényű hozzájárulást is felvállalja. A harmadik szöveg a redisztribúciós mechanizmusok integratív és sajnálatos módon dezintegratív következményeit mutatja be nagyrészt új és korábban hiányzó adatok értelmezésén keresztül. A kormányzás integrációs lehetőségeiről és következményeiről szóló rész a középszintű és a helyi kormányzási szintek, valamint a civil társadalom szervezeteinek működéséről közöl javarészt teljesen új szemléletű és információs bázisú elemzéseket. A munkaerőpiac és az egész[ség]ügyi rendszer integrációs funkcióinak az elsődlegesen fontos és kiemelkedően sikeres elemzéseit a Magyarország és a határon túli magyarok kapcsolatát, együttműködését bemutató nagyszerü összefoglaló mű, illetve az előítélet és migrációs tapasztalat kölcsönhatásait leíró munka követi. A kötet szerkesztője tudatában van annak, hogy a társadalmi integrációról való tudásunk szintézise a következő munkánk feladata, ugyanakkor abban is biztos, hogy az olvasó alapvető fontosságú szövegeket talál ebben a kötetben, amelyek teljességgel új megközelítésekkel és módszerekkel járulnak hozzá jelentősen a jelenkori magyar társadalom ismeretéhez." (7-8. old.)

A Társadalmi egyenlötlenségek és társadalmi integráció blokkot tehát a Struktúra és cselekvés. A politikai integráció mechanizmusai (Gerő Márton és Szabó Andrea írása, 45-82. old.) fejezet követi, majd a Redisztribúció és társadalmi integráció (ez Balogh Karolina, Czibere Ibolya, Kovách Imre, Nemes-Zámbó Gabriella tanulmányaként, 83-133. old.). Az ezekből kiemelhető tartalmak rövid szemlézése is vétség lenne, hisz amikor Gerő - Szabó áttekintésükben a politikai szociológia és a politikatudomány fóáramával szakítva épp azt hangsúlyozzák, milyen kölcsönös kapcsolat van a társadalom különböző csoportjainak viszonyai és a politikai folyamatok (politikai integráció, egyenlőtlenségek, politikai cselekvés, civil társadalom, újraelosztás) történeti és strukturális beágyazottságai között, akkor a kölcsönhatások elemi részletei felé térnek ki, interakciók révén keresik a rendszerszemléletü megközelítéseket (mindenekelőtt Charles Tilly munkássága alapján az újraelosztás, a civil társadalom és a politikai kommunikáció területeit), s az átjárhatóságot, csoporthatárokat tekintik át a NER önképére formálandó társadalmi eszközrendszerére koncentrálva - ezt pedig „röviden” vázlatozni szinte képtelenség. De a redisztribúció/integráció tanulmány is olyan kontextusokban vizsgálja a címadó összefüggéseket a 2015-2018 közötti társadalmi egyenlőtlenségeken, melyekben a jövedelmek formáit és jellemzőit 


\section{RECENZIÓ}

saját adatfelvétel alapján a jóléti transzferek, családtámogatások, a nyugdíjak, munkanélküli támogatások (segélyek) és hatásaik szempontjából elemzik, kitérve a projektformában újraosztott fejlesztési és egyéb források felhasználásának társadalmi következményeire, továbbá a jóléti redisztribúció egyéb velejáróira is -, hogy ezek csíziója éppen a mélységi mutatókban van, körvonalaikkal csak a tematikus horizont rajzolható meg, részleteiket pedig nem én pontosítom, hanem a szerzők érdemi adatai biztosítják tanulmányuk keretei között.

A bevezetőben is jelzett második nagyobb, Kormányzás és integráció című blokk (ugyancsak három dolgozattal) Pálné Kovács Ilona elemzésével kezdődik, aki $A$ kormányzás területi (közép) szintjének integrációs szerepe (135-166. old.) témakörében elvégzett empirikus kutatás nyomán a magyar megyék helyzetével foglalkozik, fóként arra koncentrálva, miként töltenek be integrációs-koordinációs szerepkört a középszintű önkormányzatok, megállapítva, hogy szinte teljesen periférikus pozíciót töltenek be, kitetten a más országokban is tapasztalható centralizálási törekvéseknek, de lényegileg a magyar kormányzati és helyi, különösen nagyvárosi önkormányzati elit megyeellenességével magyarázhatóan. Viszont mert a teljes önkormányzati szektor jelentős veszteséget szenvedett el az utóbbi évtizedben, kicsiny marad az esélye annak, hogy a középszintű képviseleti kormányzási szereplők a koordinációs és társadalomintegrációs szerepkörük fogyatékosságai okán jelentős hatékonysági, területi és társadalomintegrációs közreműködéssel tudnák szolgálni a kormányzás egészét. Helyi szintű, közvetlenebb kapcsolat lehetőségeit keresi tanulmányában Tamás Veronika is (167-194. old.), aki Az önkormányzatok és a helyi társadalom integrációja címen vizsgálja a politikai szférán kívül eső szereplők döntéshozatali sanszait, befolyási esélyeit. Ezen a területi integrációs szinten az állampolgári, civil szervezeti, vállalkozói, közéleti aktivista bekapcsolódás mechanizmusait keresi, mivel a kormányzati racionalitás bázisát a sokszereplős részvételi, az „új lokalizmust” mutató, a delegáció-elméleteket és partnerségi megoldásokat is figyelemmel kísérő nemzetközi összehasonlítás alapján úgy fest, nem „hozza” a helyi önkormányzatok számára jelentős előnyöket, részben a társadalom inaktivitása, részben pedig az önkormányzatok nyitottságának hiánya miatt, leszámítva egyes jól szituált társadalmi csoportok (például értelmiség, vállalkozók) erős érdekérvényesítése (demobilizáció, közvetlen profitcélok, szűkös forrásallokáció, csökkenő forrásbázis) kérdésköreit - ám a helyi társadalom nagy részében erősen korlátozott minden téren, így a közösségi kohézió szenvedi kárát mindezeknek is. A témakörök szerves egészbe fonódnak A civil társadalom változó szerepei és a társadalmi integráció témakörével Gerő Márton és Kerényi Szabina írásában (195-232. old.), melyben a civil társadalom, a társadalmi mozgalmak, a nonprofit szektor és a politikai lehetőségstruktúrák szerepelnek az integráció és a politikai részvétel tesztjeként. Kiemelik, hogy a civil társadalom politikai keretfeltételekkel összefüggő működése elvileg elválaszthatatlan lenne a politikai kontextustól, ezen belül azoktól, melyek közt az integráció különböző funkciói nem eleve adottak, így a társadalmi mozgalmak és a 


\section{RECENZIÓ}

nonprofit szektor koncepcióit is szükséges átlátni. Az elméleti, leíró modellek, valójában sokszor elvárásokkal terhelt koncepciók egy része azonban sokszor csak képzetes remények, mögöttes adataik viszont a KSH nonprofit szervezetekre vonatkozó idősorainak elemzésével illusztrálva nem csupán a 2010 óta lezajlott civil társadalmi gyengülésről bizonykodnak, hanem a civilitás részbeni szervezeti átalakulásairól is: a demokratikus elköteleződésű szervezetek központi szerepe az erőforrások és beágyazottság lassú növekedése révén biztató lehetett, de az utóbbi évtizedben „azok a szervezetek erősödtek meg, amelyek kevésbé vagy egyáltalán nem hangsúlyozták a demokratikus szempontokat, miközben a szervezetek politikai beágyazottsága folyamatosan csökkent vagy stagnált. Ezzel párhuzamosan drasztikusan csökkent azon szervezetek száma és befolyása, amelyek korábban fontos szerepet játszottak a demokratikus közéletben." (415. old.)

A lokalitás, a középszintű és helyi kormányzás, valamint a civil érdekérvényesítés leíró megjelenítései és idősorai már jelzik, hogy a politikai részvétel és a politikai lehetőségstruktúrák alighanem nagyobb rendszereket alkotnak, vagy azokba tagolódnak. Ezért is indokolt a kötet struktúrájában az Integrációs rendszerek (231-307. old.) blokk ittléte, melyben két tanulmány teszi mélységi elemzés tárgyává a részrendszerek strukturális mutatóit: a munkaerőpiac és az egészségügy a témakörük.

Az elsőben Rugalmasság biztonság nélkül. Munkaerőpiaci integrációs mechanizmusok Magyarországon a 2010-es években (233-265. old.) címen Illéssy Miklós, Huszár Ákos és Csizmadia Péter taglalja a meghatározó évtized foglalkoztatásbővítési és költséghatékonysági kérdései mellett a munkaerőpiacról kiszorultak társadalmi védettség nélkül maradását, a relatív deprivációs szintek fennmaradását és az érdekérvényesítési képességek párhuzamos csökkenését. A tézisből fakad részint a válasz is: a mai magyar társadalom egyre inkább a munkaerőpiacon kívánja integrálni a társadalom tagjait, de egyre gyengébb védelmet biztosít az idős korúaknak, a tartós betegség vagy munkanélküliség miatt munkaerőpiactól távol maradóknak, a legkevesebb erőforrással rendelkezőknek, a legkevésbé konfliktusképeseknek, illetve a problémáikat nehezebben artikulálni képeseknek - föltéve a kérdést: mennyire lesz fenntartható a gazdasági növekedés visszaesése és a külföldi foglalkoztatás világjárvány okozta esetleges bezáródása után a jelenlegi szociális modell, s marad-e a foglalkoztatás lehetséges rugalmassága egy európai szociális modell része, avagy leválik arról. Ebben a „totálképben” már részben jelen van a másik makro-mutatókkal rendelkező részrendszer is, nevezetesen a Társadalmi integráció, egészség, egészségügy (Kollányi Zsófia tanulmánya, 267-307. old.) állapotrajza, mely az egyéni, és még inkább a populációs szintű egészségi állapotban összegződni láttatja a perszonális és tömeges érdekkörű hosszabb távú folyamatokat, ezen belül az egészségi állapot alakulásának szociológiai modelljét, az alapvető okok elméletét, mely a különféle alapvető erőforrásokhoz (a tudáshoz, a pénzhez, a kapcsolatokhoz, a hatalomhoz) hozzáférés alakulását és a megoszlások rendszerét formálja. Záró tézisként az integrációs modell és az egészségi állapot kapcsolatát vizsgálja statisztikai módszerekkel, 


\section{RECENZIÓ}

melyek magyarázzák az egészségi állapot alakulásának strukturális tényezőit (például a jövedelem szintjét meg az iskolázottságot), de ugyanígy a normakövetés és a politikai aktivitás összefüggéseit is az egészségi állapottal kapcsolják össze kölcsönhatásaikban.

Itt már részben a totális kép és a részek kölcsönhatásai kezdenek dominálni. Sőt, a kötet következő blokkja már A részek és az egész keretében épül tovább Bárdi Nándor tanulmányában (311-370. old.), mely Közeli távolság. Magyarország és a határon túli magyarok viszonyairól témacímmel először száz év kormányzati vízióiról szól, majd szúkítve az utóbbi három évtized határon túli magyarokkal kapcsolatos állampolitikáját taglalja, s ennek mint integrációs kérdésnek a magyar etnokulturális közösség és az országhatárok viszonyában „a történetileg szétszakított és szétfejlődött közösségben egyenrangúként” jelen lenni kívánó, „,a kulturális, nyelvi, rokoni, baráti kapcsolataikon túl az ország 1920 előtti történetének is szerves részét képező" régiók társadalomintegrációs képességét, gyakorlatát tekinti át. Bárdi leíró módon, az eddigi szakirodalom alapján Magyarország kisebbség- és szomszédságpolitika-története szerint taglalja a magyar-magyar kapcsolatokról, a magyar politikai közösségen belül a nemzet körül zajló klasszifikációs harcról, „a modernizációs fejlődési idealizmus és a nemzeti öncélúság avagy az alkotmányos patriotizmus és a virtuális nemzet intézményesítése stratégiáinak versenyéről” kínálkozó forrásáttekintést és problémakatalógust. Összegzése alapján „a nyelvi, fogalmi birtokbavételt, illetve a határon túli magyarokhoz való viszony társadalmi megítélésének változásait" tükröző összkép, majd az 1989 utáni budapesti kormányzatok magyarságpolitikáját és a határon túli magyarok anyaországi jogi helyzetének változását" tárgyaló fejezetek következnek - idevéve a támogatáspolitika, „, Magyarországra történő, különböző célú szomszédországi bevándorlást és az áttelepülók integrálódását" mutató nyomokat is -, melyek a záró blokkban a nemzetiesítés, a kisebbségpolitika, az egymásról alkotott kép, az önkép és az etnopolitika kölcsönhatásait is megfontolás tárgyává tevő összképbe illeszkednek. Mintha részbeni folytatása is volna itt a kisebbségpolitika strukturális kérdéseinek Papp Z. Attila és Zsigmond Csilla tanulmánya (371409. old.), mely Kontextus vagy kontaktus? Elöítélet-rendszerek és migrációs tapasztalatok kérdéskörében a másság elfogadása-elutasítása mintázatainak általános és sajátosabb jellemzőit tárja föl „a kontextus és kontaktus elméleti megközelítésébe ágyazva, a szocio-demográfiai változók, a migrációs tapasztalat, a belső mobilitás és a társadalmi integráció témái szerint". Itt alighanem az állampolitika, a társadalmi struktúra és az államiság tételezett univerzumának egyik sarkkérdését érintik, nevezetesen azt a tágabb kontextust mutatják be, melyben a „társadalmi kontextus heterogenitásának elő́téletességet mérséklő hatását” megfigyelve „a migrációs tapasztalat negatív sztereotípiák lebontását elősegítő, tetten érhető jellegzetességeire" fókuszálva, sőt az időben korábbi felmérések szocio-demográfiai háttérrel összefüggő előítéletességeire is rámutatva, ezek iskolázottsággal és kapcsolati körökkel, a 


\section{RECENZIÓ}

politikai klíma előítéletek mintázataira gyakorolt hatásának feltárására is adatokat nyújtó komplexitására következtetnek.

\section{A (kulturális) mozgások funkcionalitásáról}

A fentiek nyomán az a képzetünk támadhat, hogy a második kötet (mely nem szándéka szerint második, még kevésbé másodlagos, csupán másodjára vettem kézbe) a Nagy Egész tételezett és megnevezett összefüggésrendszerének egy látszólag részkérdéseként, valójában a visszahatások révén éppoly kulcsfontosságú problematikaként jeleníthető meg. A bevezetőben (szinte azonos szavakkal és körülírással) ugyancsak Kovách Imre mint kutatásvezető és szerkesztő indítja a könyv körvonalazását, megismételve immár a Mobilitás és integráció a magyar társadalomban ${ }^{3}$ címen összefogott írások előtt „az összegző elemzés egy későbbi munka lesz” helyzetrajzot (7-8. old.), ám áttekintésében az itt közölt írások kerekded bemutatására koncentrál. A kiadó(k), a kötet választékosan ízléses külleme nem tér el, e 377 oldalas kötet is négy nagyobb fejezetre épül (Mobilitás és integráció, Területi mobilitás, Vissza a társadalomba, Határon innen, határon túl), de látható, hogy több szerző ismételt szerepeltetése részint a témaköröknek, részben meg a feltáró szempontoknak felelhetett meg. Természetesen nem lehet képem, még kevésbé rálátásom arra, miért mondjuk az ingázás, a bevándorlók befogadottsági mutatói vagy a börtönből szabadultak kérdésköre szerepel itt hangsúlyosan egy-egy tanulmányban, s miért nem a hajléktalanok vagy lecsúszott agrárvállalkozók, meggazdagodott oligarchák vagy sajtómágnások jelennek meg a rétegződés csoportképző faktoraiban, de ennek okaira a kötet részben ki is tér, részben meg láthatóvá teszi maga az egész mű, miképpen vezet a másik kötet strukturális integrációs alapkérdéseinek számos leágazása további ágazati kérdések, csoportformáló erők, funkcionális egységek konkrét egzisztálása felé. Indításával Kovách hangsúlyozza is, hogy a több partnerintézmény bevonásával készülő egész anyag a társadalmi integrációs és dezintegrációs alapkérdések folyamatait kívánja tükrözni, ha nem is egymásra olvasható fejezetek formájában, de olyan összefüggések révén, melyek az egyenlőtlenség alapkérdéseihez és az előnyök/hátrányok kialakuló rendszeréhez képest leginkább a mobilitások folyamataiban mutatnak jellegadó hatásokra.

A fentiekhez hasonló, mintegy „kivonatos absztrakt” jellegű bemutatásokra talán már nem lesz módom (nem beszélve az olvasói türelem határtalanságának fogytáról), de annyit jelezni érdemes, amennyi az önálló kötetre ad érdemi magyarázatot. Kovách szerkesztői előszava ezt így rögzíti: „A jelentős új ismereteket közreadó első témablokk két tanulmánya szerint az európai összehasonlításban a zártabbak közé

\footnotetext{
${ }^{3}$ Kovách Imre (szerk.) (2020): Integrációs mechanizmusok a magyar társadalomban. MTA Társadalomtudományi Kutatóközpont - Argumentum Kiadó, Budapest, 377 oldal
} 


\section{RECENZIÓ}

tartozó magyar társadalom objektív és megélt, szubjektív mobilitása közötti különbségeket erőteljesen befolyásolja a politikai irányultság, valamint, hogy a férfiak és a nők társadalmi helyzetének a változtatási lehetőségei összességükben még mindig inkább a nők hátrányait mutatják. A magyar társadalom integráltságának a változását 2015 és 2018 között azzal a szándékkal elemeztük a harmadik tanulmányban, hogy megvonjuk a 2010-et követő korszak társadalomra vonatkozó kormányzati törekvéseinek a mérlegét, ugyanakkor bemutassuk az integrációt központba állító módszer és szemlélet társadalomszerkezeti mozgásokat és azok okait is regisztrálni és elemezni képes előnyeit. A negyedik tanulmány elméleti igénnyel és kiemelkedő eredménnyel foglalja össze a magyar társadalom politikai integrációjáról való ismereteinket. A második rész témái a területi mobilitás és az integráció összefüggéseinek, a kapcsolati tőke és a földrajzi mobilitás, valamint az ingázásra ható tényezőknek a bemutatása. A következő rész a szociális munka mobilitási és integrációs folyamatokba történő, korántsem magától értetődően pozitív beavatkozásáról, valamint a börtönből szabadultak visszaintegrálódásának a korlátairól szól adatgazdag és elmélyült elemzésekkel. A kötetzáró tanulmányok újdonságtartalma is jelentős: a nyugati magyar diaszpórák anyaországhoz kötődő és a befogadó államokhoz is kapcsolódó kettős integrációjának a dilemmáiba, motiválóiba vezetik be az olvasót." (7-8. old.) A kötet tehát nem I/2. könyv, hanem önálló szociológiatudományi opusz, funkciója ugyanakkor szervesen az előzőekre épül, azokat ki is egészíti és bizonyos téri-társadalmi-politikai kontextusokban valorizálja is.

Az első elemzés (Huszár Ákos és Szabó Andrea munkája, 11-33. old.) mindjárt a belső összefüggések, az inter- és intragenerációs szubjektív társadalmi mobilitás, a pártpreferenciák és a politikai integráció részkérdései felé kalauzol, „nem a társadalmi mobilitás hagyományosan vizsgált objektív dimenzióit, hanem annak az egyénben lecsapódó érzetét, a szubjektív mobilitást vizsgálva", melyben a közelmúlt évek szociológiai, politikatudományi vizsgálódásaiban tükröződő, a média által erősen vezérelt társadalmak objektív mutatókon túli, sőt „valóságon túli, úgynevezett megélt valóságnak, vagy ahogy a politikatudomány ezt mondja: a 'post-truth' világnak" szubjektív tüneteire koncentrálnak. A szubjektív mobilitás ilyetén érték-, ideológiaés politikavezérelt, sőt befolyásolt rétegződési hatásai „a mobilitás szempontjából inkább állandóságot, stabilitást mutató társadalom, a szubjektum szintjén lehet erősen felfelé mobilnak megélt, dinamikus és kedvező konnotációjú" világ formálódásáról vallanak, a társadalom tagjai bár hónapról hónapra kedvezőtlenebbé váló helyzetbe kerülnek, „objektív mobilitási mutatókkal ez az érzet nem támasztható alá. Ennek egyik kézzelfogható példája a Fidesz 2006-os 'Rosszabbul élünk, mint 4 esztendeje!' kampányszlogenje, amely arra próbált rávilágítani, hogy a társadalom súlyos veszteségeket szenvedett az MSZP által vezetett 2002-2006 közötti időszakban" - így a feltörekvés e meghatározó korszakát egyúttal a mediatizált új közfelfogás korszakának is láthatjuk. Szintúgy a látszatok és léthelyzetek tényadati, valamint szubjektív képük kínálja a dilemma megfogalmazását $A$ társadalmi mobilitás egyen- 


\section{RECENZIÓ}

lőtlensége a nôk és a férfiak között. Közeledés vagy távolodás? címen (Huszár Ákos, Balogh Karolina és Győri Ágnes tanulmányában, 35-57. old.), akik a származás és az egyéni társadalmi pozíció összefüggését a nők és a férfiak mobilitási jellemzői közötti különbségek áttekintésében mutatják ki, hátrányos helyzetek és ezek javulási trendje szerint is. Ugyanakkor a nemek közötti egyenlőtlenségi relációkban arra a kedvezőtlen tendenciára is rámutatnak, hogy erősödik a magyar társadalom bezáródása a mobilitás mértékének csökkenésével, s ebben ugyan a nők abszolút mobilitási mutatói összességében már kedvezőbben alakulnak, mint a férfiakéi, ez azonban nem jelenti azt, hogy a mobilitási esélyeik is kedvezőbbek. A Mobilitás és integráció főfejezet módszertani értékének is hangadó tanulmánya Gerő Márton, Hajdu Gábor, Kovách Imre, Kristóf Luca és Szabó Andrea alapozó áttekintése (A magyar társadalom integrációja 2015, 2018, lásd 59-88. old.), akik a két időpontban megformált integrációs modellek szerkesztésében felhasznált dimenziók összehasonlításával elemzik a magyar társadalom integrációjának változásait a két adatfelvételi időpont között, láttatva a modellek formálódását és eredményeit, a kapott eredményeket összehasonlítva a kormányzat kinyilvánított társadalompolitikai céljaival. „A tanulmány eredményei, a látens profilelemzés a modellalkotáshoz, a modelleket létrehozó változók megoszlásai és statisztikai kapcsolatai jól alkalmazhatók és bizonyítják, hogy az integrációs modell alkalmas nemcsak a társadalmi egyenlőtlenségek és az integráció adott állapotának a leírására, hanem azok két időszak közötti elmozdulásainak, módosulásainak az elemzésére is. A társadalmi egyenlőtlenségek és integráció nagyon csekély mértékben módosultak 2015 és 2018 között. A társadalom politikai integrációja jelentős mértékben felerősödött" - írják összegzésképpen, amivel egyúttal fel is vezetik Szabó Andrea és Gerő Márton itt következő áttekintését $A$ magyar társadalom politikai integrációja címmel (89-126. old.), akik az utóbbi fél évtized saját elemzéseit a politikai rendszer, a folyamatok integrációs hatásai, az értékrend, a részvétel és az interakciók mechanizmusai révén újrateremtődött együttélési kérdéseit úgy összegzik, mint a politikai alrendszer múködtetéséhez szükséges feltételeket, amelyek a korábbi mintázatokhoz képest immár a habermasi értelemben vett nyilvánosság-mintázat új politikai kultúrához vezető útját jelzik egy 2018-as reprezentatív adatfelvétel tanúsága szerint.

A kötet második nagyobb egységének a Területi mobilitás rendszerét fókuszált kutatásokkal, a kapcsolati tőke, földrajzi mobilitás és ennek nemekre gyakorolt hatása szempontjából „elkülönült” vizsgálódásokkal alátámasztó tanulmány-hármasa adja. Talán nem szorul részletezőbb magyarázatra a struktúraformáló mechanizmusok mellett az integráció térbeniségének fontossága, de a Területi mobilitás és a magyar társadalom integrációs csoportjai című elemzéssel (Csizmady Adrienne, Győri Ágnes, Kőszeghy Lea és Rácz Attila munkájával, 129-161. old.) a demográfiai, munkaerőpiaci, urbanizációs, szubjektív térátélési és objektív (KSH) adatsoros mutatókkal ékes tanulmány a Társadalomtudományi Kutatóközpont Szociológiai Intézete által 2018-ban, országosan reprezentatív mintán végzett kérdőíves kutatás anyagá- 


\section{RECENZIÓ}

ból is kiemeli, hogy a háztartások területi mobilitási lehetőségeit és hajlandóságát befolyásoló tényezők közül a lakás- és munkaerőpiaci helyzet mellett a területi mobilitás társadalmi különbségeinek megértésében miért fontos a mobilitási lehetőségeket és hajlandóságot befolyásoló tényezők, a lakásmobilitás, az alkalmazkodási és normakövető rutinok, valamint a kapcsolatgazdagság politikai aktivitásra gyakorolt hatásainak tisztább áttekintése. Közelítően hasonló az ugyancsak kapcsolathálózatok, IT-eszközhasználat és távolságkezelés kérdése Dávid Beáta, Albert Fruzsina és Huszti Éva írásában, akik Kapcsolati tőke és földrajzi mobilitás címen (163-192. old.) „a kapcsolati tőke indikátoraként használt, a személyes kapcsolathálózatok legszűkebb, erős kapcsolatokat tartalmazó körének, az úgynevezett bizalmas beszélgetési hálózatoknak az alakulását" tekintették át a 2015-2018 közti időszak adataiból kibontakozó változások nyomon követésével. Itt már fölmerül az is, amit részleteiben elemez Bakó Tamás és Kálmán Judit Változott-e az ingázásban a nemek közötti egyenlötlenség? Az ingázási időre ható tényezők és változásuk 1990 és 2011 között Magyarországon címen (193-219. old.). Írásukban nemzetközi összehasonlítás révén kerülnek közelebb az ingázási idő, a helyi munkaerőpiac, a női foglalkoztatás, a népszámlálás, a szelekciós modell integrációs kérdéseihez, közelebbről a munka miatti ingázás modern jelenségét a munkaerőpiac és a lakáspiac térbeli interakciójának eredményeként tekintő aspektushoz. Az egyén részéről racionálisnak tűnő választás, ha jobb lakáskörülmények vagy előnyösebb munkalehetőség, magasabb bérszínvonal révén kompenzál térbeli távolságot és talán a mobilitással járó fáradságot, de (mint a nők esetében egyre jellemzőbb) a leíró típusú ingázási mintázatok révén egy új szempontú szelekciós ökonometriai modellel vizsgálhatók az ingázási időre ható tényezők. Eszerint bár a nők egyre jobban felzárkóztak a férfiakhoz számos téren, ám eredményeik szerint a lakóhely földrajzi elhelyezkedése lényegesen nagyobb hatással bír, mint bármelyik egyéni szintű demográfiai változó, s ez komoly kihatással lehet az ingázás társadalmi költségeire és jóléti hatásaira - összegzik rálátásukat a fölvetett változás-kérdésre.

Új aspektus kerül szemünk elé a következő blokk (Vissza a társadalomba) két tanulmányában, ahol először Rácz Andrea mutatja be $A$ szociális munka intervencióinak hatása a társadalmi mobilitásra és immobilitásra témakör perspektíváit (223248. old.), ezen belül a szociális munka mozgásterét a hátrányos helyzetű, kirekesztett családok és egyének támogatásában, a rendszer diszfunkcionális müködése és a kliensek helyzetének konzerválása szempontjából, mindenekelőtt a gyermekes családok, a társadalmi mobilitás és ellátórendszer működése terén a jól-léttel öszszefüggésben, a gyermekvédelmi rendszer, a kirekesztett léthelyzetek és állapotok rögzülését, konzerválását eredményező diszfunkcionalitások hatásával számolva. Már más, de a mobilitásnak a diszkriminációval, közösségi és jogi megbélyegzettséggel találkozó szféráiban izgalmas terület felé kalauzol Boza István, Csáki Anikó, Ilyés Virág, Köllő János, Kőműves Zsófia, Márk Lili és Mészáros Mercedes kollektív elemzése (Keresleti korlátok a börtönből szabadultak reintegrációjában, 249-291. 


\section{RECENZIÓ}

old.), melyben a fogvatartottak és a diszkrimiáció magyarországi gyakorlatát szemügyre véve közel negyvenezer, a vizsgált időszakban legalább egyszer fogva tartott személyről készítettek áttekintést a vállalatok alkalmazási stratégiájában jelen lévő kockázatvállalásról és az érintettek visszailleszkedési esélyeit komolyan tanulmányozandó kérdéskörökről.

Esélytelen esélyek, avagy szépségtapaszt hordozó tematika felé kanyarodik el a kötet záró tárgyköre, a Határon innen, határon túl blokk, melyben a diaszpóra-kérdések és a bevándorlás közeli tematikái rímelnek az előző tanulmánysor föltette kérdésekre is. A tárgykör evidensen meghatározó írása Papp Z. Attila, Kovács Eszter és Kováts András dolgozata (295-324. old.), melyben Magyar diaszpóra és az anyaország. Diaszporizáció és diaszpórapolitika tárgykörébe emelve egy új, fiatal, az anyaország és a transznacionális perspektívák közötti helyzetét megfogalmazó népességcsoport kapcsolatrendszeri kultúráját tematizálják a nemzetközi diaszpórapolitikai szakirodalom elméleti keretei között és a kormányzati politika anyaországképzeteinek tárgykörében. A diaszpórában élő magyarság kapcsolata felől valamiképpen gondolkodik a magyar politika, valamiféle szerepet szán is nekik a magyar nemzetépítésben vagy külpolitikában, de másképpen viszonyul az anyaország a külföldön (nyugaton) élő nemzettagokhoz, mint azt a képzetek szintjén fölvázolhatnánk. „Saját empirikus adataink segítségével vizsgáljuk azt is, hogy a külföldre migrált magyarok hogyan viszonyulnak Magyarországhoz és új, lakóhelyük szerinti országukhoz. Képet adunk arról, hogy a külföldön élők milyen módon intézményesülnek új környezetükben, és választ adunk arra is, hogy a különféle szerveződéseik egy új diaszpóra kialakulásához vagy inkább csak egy transznacionális mozgás állandósulásához vezetnek" - írják összegző kivonatukban, jelezve írásuk végén, hogy a diaszpóra-politika hosszabb távú intézményes fenntartása és szilárdabb intézményesülése még számos előre nem látható globális, valamint anyaországi hatástól függ. Ilyen függések egyike a könyv záró tanulmányában, Feischmidt Margit és Zakariás Ildikó írásában (325-351. old.) az európai szelektív mobilitási rendszerbe való helyezkedés és a szolidaritás összefüggéseinek kérdésköre (Szolidaritás és társadalmi mobilitás. Magyar bevándorlók jótékonysága és fizetett munkája a német bevándorlási rendszerben), ahol a menekültellátásban végzett jótékonyság és a fizetett munka európai migránsok strukturális és érzékelt munkaerőpiaci helyzetére gyakorolt hatását elemzik. Vizsgálatuk „a Németországban élő magyarokra irányult, módszere online survey és interjús adatfelvétel. A tanulmány megállapítja, hogy az önkéntesen végzett szolidaritási munka növelte a magyar migránsok esélyét arra, hogy Németországban fizetett munkát találjanak, ami sokak számára az előrelépést jelentette a formális munkaerőpiacon is. Ez a strukturális összefüggés az értelmezések szintjén a migráns élethelyzetek azonosságának diskurzusait és a személyes példákra hivatkozó meritokratikus diskurzusokat erősítette." Adatsoraikban tehát a dezintegrációs hazai folyamatok külföldön integrációs ellenoldala kap reflektorfényt, sorok közt jelezve mintegy azt is, hogy a „migránsellenző” hazai bel- és EU-politikák inkább a be-, 


\section{RECENZIÓ}

s kevésbé a kibontakozások irányába hatnak a makrostruktúra kulturális hátterében.

A kötetek bemutatásánál praktikusan használtam a kötet végén elhelyezett (magyar és angol) absztraktokat is, ezek nélkül a több mint 800 oldalas tanulmánytömeg áttekinthetetlen is lett volna, vagy olyan terjengős, ami ugyan a mobilitás és az integráció kérdéskörét talán érinthette volna további dimenziók terén, de tudományos nóvumaikat, párhuzamaikat és rendszerképző motívumaik részletrajzát biztosan nem adhatta volna. Így is egy harmadik olvasat keletkezett, ami talán nem baj, legalább kifejezhetem benne a szakmai vagy távolsági érdeklődő olvasó iránti szolidaritásomat. A kötetek egy több éves kollektív kutatói munka tudományos eredményei, melyeket a szerzők és szerkesztő „a NER rendszerének széleskörü leírása és egyben mérlege is" végszóval zárnak a kötet hátoldalán. Végszónak még korai összegzés, a fogyatkozó integritások időszakában azonban a „legfőképpen politikailag integrált” magyar társadalom e sajátos rajzolata mindenesetre nemcsak hiánypótló, de súlyosan lehangoló is. 